\title{
Pineapple Juice as a Natural Catalyst: An Excellent Catalyst for Biginelli Reaction
}

\author{
Suresh Patil", Swati D. Jadhav, Sanjeevani Y. Mane \\ Organic Research Laboratory, Department of Chemistry, P.D.V.P. College, Tasgaon, India \\ E-mail: ${ }^{*}$ sanyujapatil@yahoo.com \\ Received May 8, 2011; revised June 23, 2011; accepted July 5, 2011
}

\begin{abstract}
An efficient and greener synthesis of a series of dihydropyrimidinone (DHPMs) derivatives were accomplished via three-component one-pot cyclocondensation between substituted aryl aldehydes, diketone/ketoester and urea. This solvent free approach is totally nonpolluting having several advantages such as shorter reaction time, mild reaction conditions, simple workup and reduced environmental impact.
\end{abstract}

Keywords: Biginelli, Natural Catalyst, Pineapple Juice, Dihydropyrimidinone.

\section{Introduction}

Among the challenges for chemists include discovery and development of non-hazardous and simple environmentally safe chemical processes for selective synthesis by identifying alternative reaction conditions and solvents for much improved selectivity, energy conservation and even less hazardous waste generation are not desirable and inherently safer chemical products. Therefore, to address depletion of natural resources and preservation of ecosystem it is just urgent to adopt so called "greener technologies" to make chemical agents for well being of human health. Due to acidic nature $(\mathrm{pH}=3.7)$ pineapple juice as a natural catalyst has been found to be a suitable replacement for various homogeneous acid catalysts.

In literature number organic reactions are reported in which natural catalyst like clay [1-3], phosphates [4,5], gold [5], animal bone [6] etc. are employed. In continuation of our research work in application of natural acids as catalyst, here, we report a solvent free one pot cyclocondensation reaction of substituted aryl aldehydes, diketone/ketoester and urea (Scheme 1) with good yields.
Pineapple (Ananas comosus) is sometimes called the King of Fruit [7]. Pineapple is grown extensively in Hawaii, Philippines, Caribbean area, Malaysia, Taiwan, Thailand, Australia, Mexico, Kenya and South Africa. Pineapple has long been one of the most popular of the non-citrus tropical and subtropical fruits, largely because of its attractive flavour and refreshing sugar-acid balance [8]. For the present work, we have used extract of pineapple as natural catalyst for synthesis of dihydropyrimidinone (DHPMs). The main ingredients of $100 \mathrm{~g}$ pineapple contain 47 - 52 calories, water $(85.3-87.0 \mathrm{~g})$, protein $(0.4-0.7 \mathrm{~g})$, fat $(0.2-0.3 \mathrm{~g})$, total carbohydrate (11.6 - $13.7 \mathrm{~g})$, fiber (0.4 - $0.5 \mathrm{~g})$, ash (0.3 - $0.4 \mathrm{~g})$, calcium (17 - $18 \mathrm{mg}$ ), phosphorus (8 - $12 \mathrm{mg}$ ), iron (0.5 mg), sodium (1 - $2 \mathrm{mg}$ ) and potassium (125 - $146 \mathrm{mg})$ [9]. It also contains $12 \%-15 \%$ sugars of which two-third is in the form of sucrose and the rest are glucose and fructose and $0.6 \%-1.2 \%$ acid of which $87 \%$ is citric acid and $13 \%$ is malic acid $[10,11]$. The composition of the juice varies with geographical, cultural and seasonal harvesting and processing.

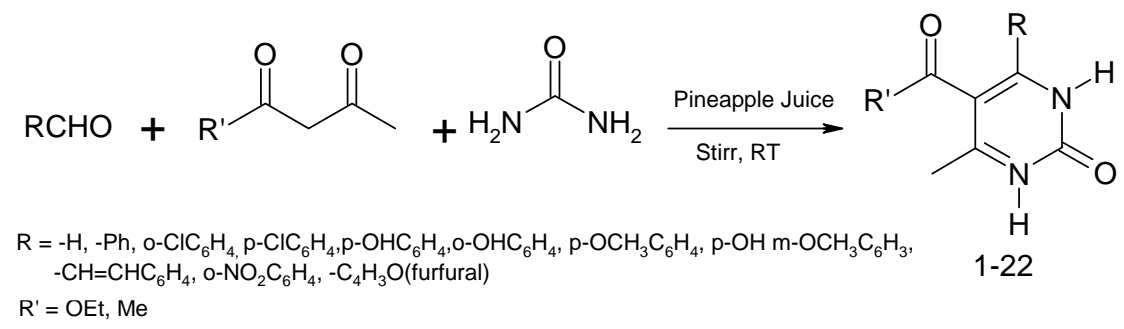

Scheme 1. Synthesis of dihydropyrimidinones. 
The extract of pineapple is acidic having $\mathrm{pH} 3.7$ and the acidity percentage is $53.5 \%$ and hence it will be worked as acid catalyst for cyclocondensation. Therefore, we have used this extract as natural catalyst for synthesis of DHPMs.

The Italian chemist Pietro Biginelli (1893, University of Florence) for the first time reported on the acid-catalyzed cyclocondensation reaction of ethyl acetoacetate, benzaldehyde, and urea [12]. The three components reaction mixture in ethanol was simply heated with a catalytic amount of $\mathrm{HCl}$ at reflux temperature and the product that precipitated on cooling the reaction mixture was identified as 3,4-dihydropyrimidin-2(1H)-one. This reaction is nowadays referred to as the Biginelli reaction, Biginelli condensation or as the Biginelli dihydropyrimidine synthesis. However, this method is suffered from drawbacks of the longer reaction time and lower yields, hence reaction remained unfocused in the last century. But due to important biological properties of DHPMs, the interest in their synthesis has been increased in the last two decades. Much effort has been made recently to improve and modify this reaction. This gave inspiration to organic chemists to find out more suitable protocol and simpler methods for the synthesis of DHPMs.

DHPM and its derivatives are found in a large family of natural products with broad biological activities, due to which they become important classes of organic compounds. They generally possess intriguing therapeutic and pharmacological properties [13-15]. Several of their functionalized derivatives are used as calcium channel modu- lators [13-16], Ca-antagonists [16-18] and vasodilative, antihypertensive [19].

For Biginelli reaction, large number of methods have been reported to synthesize DHPMs by altering catalyst. Of them various homogeneous catalysts such as $\mathrm{Mg}\left(\mathrm{NO}_{3}\right)_{2}$ [20], $\mathrm{Pb}\left(\mathrm{NO}_{3}\right)_{2}$ [21], $\mathrm{LaCl}_{3} \cdot 7 \mathrm{H}_{2} \mathrm{O}$ [22], $\mathrm{P}_{2} \mathrm{O}_{5}$ [23]. Recently Lewis acids like DDQ [24], $\operatorname{InBr}_{3}$ [25], $\mathrm{CaCl}_{2}$ [26], $\mathrm{Y}(\mathrm{OAc})_{3}$ [27], $\mathrm{ZnCl}_{2}$ [28], $\mathrm{RuCl}_{3}$ [29], Metal triflimides $\mathrm{Ni}\left(\mathrm{NTf}_{2}\right)_{2}$ [30] etc. have been extensively reported in the literature Biginelli reactions. Apart from these, the Bronsted acids such as $p$-TSA [31], almost neutral catalyst $\mathrm{Zn}\left(\mathrm{BF}_{4}\right)_{2}$ [32] also reported Heterogeneous catalysts such as E4a [33], $\mathrm{SiO}_{2}$-Cl [34], AMA [35], KSF(montmorillonite) [36], zeolites like HZSM-5, HY, MCM-41 [37] have also been employed. Synthesis of DHPMs can also be catalyzed by ionic liquids [38].

The limitations in using the above mentioned catalysts were such as long reaction time, elevated reaction temperature, harsh reaction conditions, use of expensive reagents, moderate yields of the products, use of harmful organic solvents and toxic and hazardous transition metals (Table 1).

\section{Results and Discussion}

Herein, we, report a single step synthesis of DHPMs using a pineapple juice as natural catalyst under solventfree conditions. As per literature survey, there are no earlier reports of pineapple juice as catalyst for Biginelli reaction. In addition to its clean and simplicity, this catalyst resulted in higher yields for different aromatic aldehydes (Table 2).

\section{Conclusions}

We have developed an eco-friendly and economic process for the synthesis of DHPMs by pineapple juice as a catalyst with good yields. This solvent free approach is totally nonpolluting and there no any use of toxic materials, quantifying it as a green approach to this cyclocon densation reaction. In addition to this, it involved mild.

\section{Experimental Section}

\subsection{General Process for Preparation of Pineapple Juice}

Fresh pineapple (Ananas comosus) was procured locally. The crown and stem portions were removed and the skin reaction conditions and simple workup was peeled using

Table 1. Comparison for different catalysts used for synthesis of DHPMs $\left(\mathrm{R}=\mathrm{p}-\mathrm{OCH}_{3} \mathrm{C}_{6} \mathrm{H}_{4}\right)$.

\begin{tabular}{|c|c|c|c|c|}
\hline Entry & Catalyst & Time & Temperature & Yield (\%) \\
\hline 1 & p-TSA [31] & $1 \mathrm{hr}$ & Refluxed in EtOH & 90 \\
\hline 2 & $\mathrm{RuCl}_{3}$ [29] & $4.5 \mathrm{hr}$ & Reflux in $\mathrm{N}_{2}$ atm & 82 \\
\hline 3 & $\mathrm{Zn}(\mathrm{BF})_{4}[32]$ & $4 \mathrm{hr}$ & Stirring at RT & 71 \\
\hline 4 & $\mathrm{Y}(\mathrm{OAC})_{3}[27]$ & $4.5 \mathrm{hr}$ & $115^{\circ} \mathrm{C}$ & 89 \\
\hline 5 & $\mathrm{Mg}\left(\mathrm{NO}_{3}\right)_{2}[20]$ & $45 \mathrm{~min}$ & Refluxed & 90 \\
\hline 6 & $\mathrm{CaCl}_{2}[26]$ & $2 \mathrm{hr}$ & Refluxed in EtOH & 98 \\
\hline 7 & $\mathrm{InBr}_{3}[25]$ & $7 \mathrm{hr}$ & Refluxed in $\mathrm{EtOH}$ & 97 \\
\hline 8 & $\mathrm{~Pb}\left(\mathrm{NO}_{3}\right)_{2}[21]$ & $180 \mathrm{~min}$ & Refluxed in $\mathrm{CH}_{3} \mathrm{CN}$ & 89 \\
\hline 9 & $\mathrm{P}_{2} \mathrm{O}_{5}[23]$ & $1.5 \mathrm{hr}$ & Refluxed at $100^{\circ} \mathrm{C}$ & 94 \\
\hline 10 & SA \& SSA [39] & $10 \mathrm{~min}$ & Reflux $120^{\circ} \mathrm{C}$ & 86 \\
\hline 11 & E4a [33] & $8 \mathrm{hr}$ & Heated at $80^{\circ} \mathrm{C}$ & 91 \\
\hline 12 & AMA [35] & $35 \mathrm{~min}$ & $\begin{array}{c}\text { Heated at } 60^{\circ} \mathrm{C} \\
\text { in } \mathrm{EtOH}\end{array}$ & 96 \\
\hline 13 & $\begin{array}{l}\text { Yattria-Zirconia } \\
\text { Lewis acid [40] }\end{array}$ & $6 \mathrm{hr}$ & Aq. $\mathrm{CH}_{3} \mathrm{CN} 60^{\circ} \mathrm{C}$ & 92 \\
\hline 14 & $\begin{array}{c}\text { Silica chloride } \\
\text { [34] }\end{array}$ & $3 \mathrm{hr}$ & Heated at $80^{\circ} \mathrm{C}$ & 90 \\
\hline 15 & Pineapple & $3.5 \mathrm{hr}$ & Stirring at RT & 82 \\
\hline
\end{tabular}


Table 2. Pineapple Juice catalyzed synthesis of DHPMs.

\begin{tabular}{|c|c|c|c|c|c|c|}
\hline \multirow[b]{2}{*}{ Entry } & \multirow[b]{2}{*}{$\mathbf{R}$} & \multirow[b]{2}{*}{$\mathbf{R}^{1}$} & \multirow[b]{2}{*}{ Time (hours) } & \multirow[b]{2}{*}{ Yield (\%) } & \multicolumn{2}{|c|}{ M.P. } \\
\hline & & & & & Found & Reported \\
\hline 1 & $\mathrm{H}$ & OEt & 3.5 & 60 & 232 & - \\
\hline 2 & & OEt & 2.5 & 82 & 207 & 202 [32] \\
\hline 3 & & OEt & 3.5 & 81 & 216 & 218 [27] \\
\hline 4 & & OEt & 4.5 & 85 & 213 & 215 [32] \\
\hline 5 & & OEt & 2 & 86 & 222 & 226 [32] \\
\hline 6 & & OEt & 3.5 & 79 & 202 & 201 [32] \\
\hline 7 & & OEt & 3.5 & 82 & 203 & 203 [32] \\
\hline 8 & & OEt & 2.5 & 85 & 215 & 215 [41] \\
\hline 9 & & OEt & 2 & 89 & 230 & 232 [32] \\
\hline 10 & & OEt & 3.5 & 87 & 209 & 208 [32] \\
\hline 11 & & OEt & 5 & 88 & 204 & $203-205[21]$ \\
\hline 12 & $\mathrm{H}$ & $\mathrm{Me}$ & 3.5 & 61 & 230 & -- \\
\hline 13 & & $\mathrm{Me}$ & 3.5 & 90 & 232 & 233 [32] \\
\hline 14 & & $\mathrm{Me}$ & 3 & 92 & 240 & - \\
\hline 15 & & $\mathrm{Me}$ & 5.5 & 93 & 277 & - \\
\hline 16 & & $\mathrm{Me}$ & 3 & 90 & 256 & - \\
\hline 17 & & $\mathrm{Me}$ & 4 & 88 & 220 & - \\
\hline 18 & & Me & 3 & 93 & 172 & 166 [32] \\
\hline
\end{tabular}




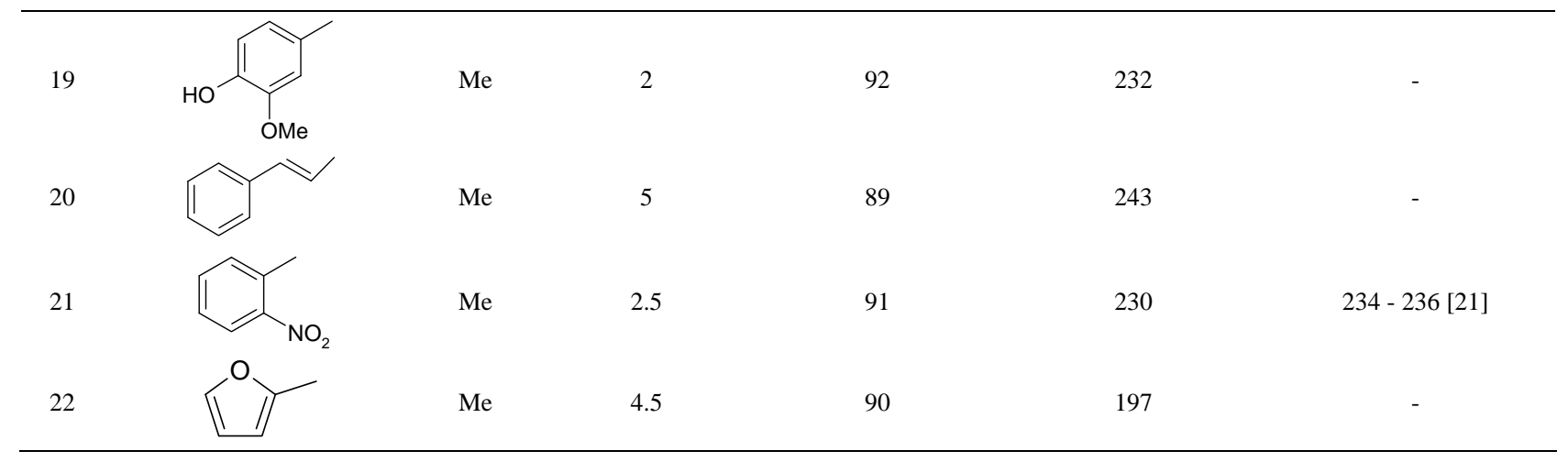

knife. Then the fruit was sliced and the fruit slices pressed in a fruit juicer for one to two minutes to get the semisolid mass which was then filtered through cotton to get liquid pineapple juice.

\subsection{General Procedure for Synthesis of 5-Ethoxycarbonyl-6-methyl-4-(4-methoxyph enyl)-3,4-dihydropyrimidin-2(1H)-one}

The synthesis of 5-ethoxycarbonyl-6-methyl-4-(4-methoxyphenyl)-3,4-dihydropyrimidin-2(1H)-one is described as a representative example : The equimolar quantities of p-metho-xy- benzaldehyde (1.36 g, $10 \mathrm{mmol})$, ethyl acetoacetate, $(1.30 \mathrm{~g}, 10 \mathrm{mmol})$ and urea $(0.6 \mathrm{~g}, 10 \mathrm{mmol})$ in $1 \mathrm{ml}$ pineapple juice were stirred for 3.5 hours at room temperature with monitoring by TLC. Then the reaction mixture was filtered, washed with little water. The yellow solid obtained was then recrystallized with ethanol to get fine yellow crystals of 5-ethoxycarbonyl-6-methyl4-(4-methoxyphenyl)-3,4-dihydropyrimidin-2(1H)-one. The formation of the compound was confirmed by IR, NMR and its melting point.

This procedure is followed for the synthesis of all the DHPMs listed in Table 2.

\subsection{Spectral Data for Representative Compounds}

5-ethoxycarbonyl-6-methyl-4-(4-methoxyphenyl)-3,4-dih ydropyrimidin-2(1H)-one (Compound 7 Table 2):

IR $\left(\mathrm{CHCl}_{3}, \mathrm{~cm}^{-1}\right)$ : $\max 3230,1720,1690 \mathrm{~cm}^{-1}$.

${ }^{1} \mathrm{H}$ NMR $\left(\mathrm{CDCl}_{3}\right): 1.14$ (s, 3H, $\left.-\mathrm{OCH}_{2} \mathrm{CH}_{3}\right), 2.32$ (s, $\left.3 \mathrm{H},-\mathrm{CH}_{3}\right), 3.78$ (s, $\left.3 \mathrm{H},-\mathrm{OCH}_{3}\right), 4.05\left(\mathrm{~s}, 2 \mathrm{H},-\mathrm{OCH}_{2} \mathrm{CH}_{3}\right)$, 5.34 (s, 1H,-NH), 5.90 (s, 1H,-NH), 6.84 (s, 2H, Ar-H), 7.21 (s, 2H, Ar-H), 8.42 (s, 1H, -CH) (Figure 1).

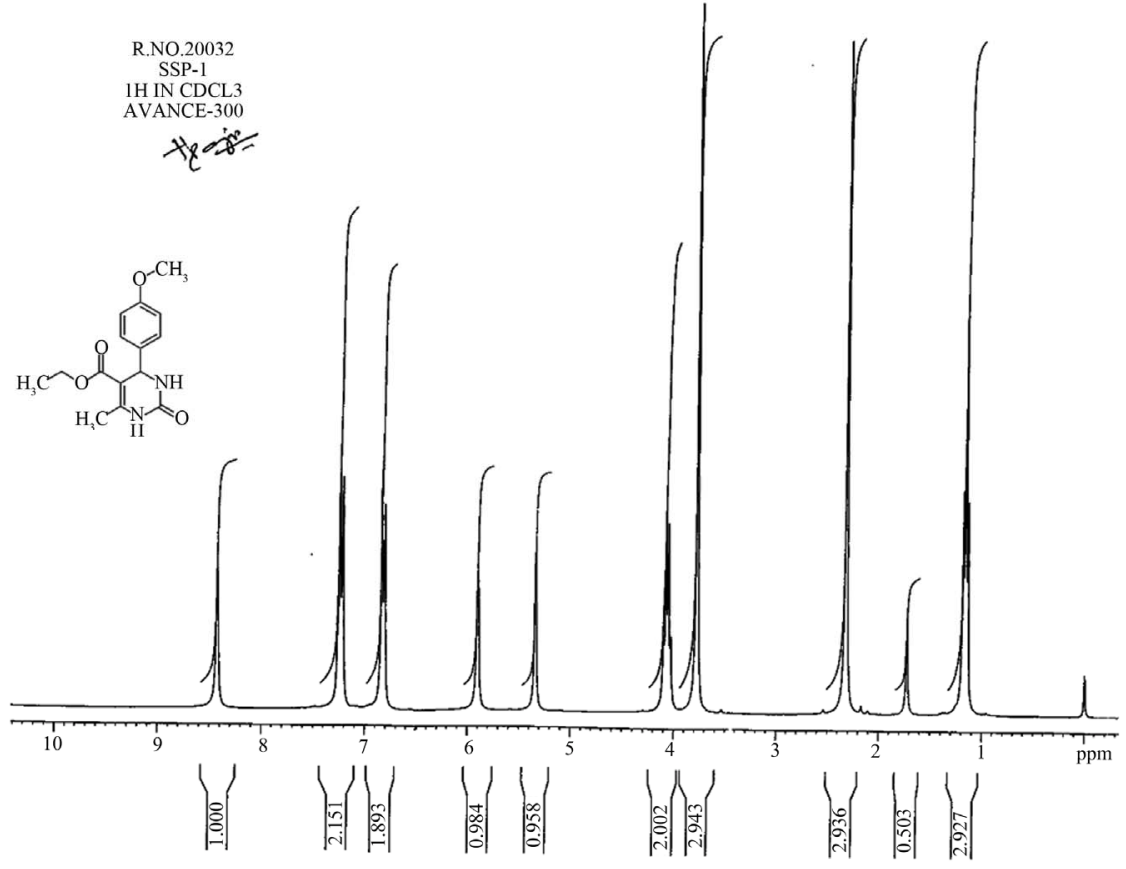

Figure 1. NMR Spectrum (1). 


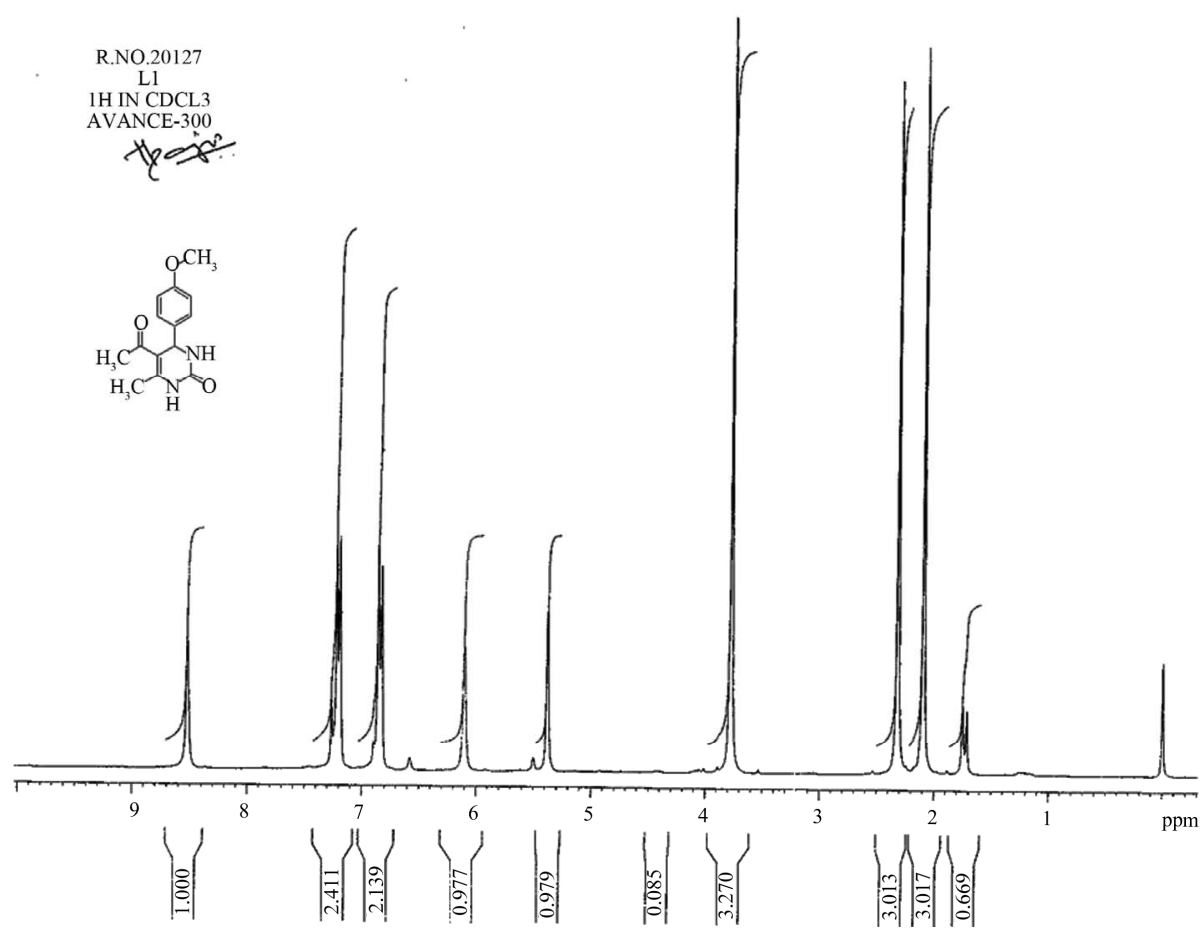

Figure 2. NMR Spectrum (2).

5-acetyl-6-methyl-4-(4-methoxyphenyl)-3,4-dihydropyri midin-2(1H)-one (Compound 18 Table 2)

IR $\left(\mathrm{CHCl}_{3}, \mathrm{~cm}^{-1}\right)$ : $\max 3235,1721,1692 \mathrm{~cm}^{-1}$.

${ }^{1} \mathrm{H}$ NMR $\left(\mathrm{CDCl}_{3}\right): 2.09$ (s, 3H, $\left.-\mathrm{CH}_{3}\right), 2.32$ (s, 3H, $-\mathrm{CH}_{3}$ ), 3.77 (s, 3H, $-\mathrm{OCH}_{3}$ ), 5.37 (s, 1H, -NH), 6.10 (s, $1 \mathrm{H},-\mathrm{NH}), 6.85$ (s, 2H, Ar-H), 7.21 (s, 2H, Ar-H), 8.52 (s, $1 \mathrm{H},-\mathrm{CH})$ (Figure 2).

\section{Acknowledgements}

Authors gratefully acknowledge the financial support from the UGC, New Delhi.

\section{References}

[1] E. Ramesh and R. Raghunathan, "Microwave-Assisted K-10 Montmorillonite Clay-Mediated Knoevenagel Hetero-Diels-Alder Reactions: A Novel Protocol for the Synthesis of Polycyclic Pyrano[2,3,4- $k l$ ]xanthene Derivatives," Synthetic Communications, Vol. 39, No. 4, 2009, pp. 613-625. doi:10.1080/00397910802417825

[2] D. Habibi and O. Marvi, "Montmorillonite KSF and Montmorillonite K-10 Clays as Efficient Catalyst for the Solventless Synthesis a Bismaleimides and Bisphthlimides Using Microwave Irradiation,” Arkivoc, (XIII), 2006, pp. 8-15.

[3] M. Zahouily, B. Mounir, H. Charki, A. Mezdar, B. Bahlaouan and M. Ouammou, "Investigation of the Basic Catalytic Activity of Natural Phosphates in the Michael
Condensation," Arkivoc, (XIII), 2006, pp. 178-186.

[4] M. Zahouily, B. Bahlaouan, A. Rayadh and S. Sebti, "Natural Phosphate and Potassium Fluoride Doped Natural Phosphate: Efficient Catalysts for the Construction of a Carbon-Nitrogen Bond,” Tetrahedron Letters, Vol. 45, No. 12, 2004, pp. 4135-4138.

[5] E. Genin, P. Y. Toullec, P. Marie, S. Antoniotti, C. Brancour, J. P. Genêt and V. Michelet, "Gold Catalysis in Organic Synthesis: Efficient Intramolecular Cyclization of $\gamma$-Acetylenic Carboxylic Acids to 5-Exo-AlkylideneButyrolactones,” Arkivoc, (V), 2007, pp. 67-78.

[6] Y. Riadi, R. Mamouni, R. Azzalou, R. Boulahjar, Y. Abrouki, M. El. Haddad, S. Routier, G. Guillaumet and S. Lazar, "Animal Bone Meal as an Efficient Catalyst for Crossed-Aldol Condensation,” Tetrahedron Letters, Vol. 51, No. 51, 2010, pp. 6715-6717. doi:10.1016/j.tetlet.2010.10.056

[7] D. Arthey, "Fruit and Vegetable Product," In: M. D. Ranken, R. C. Kill and C. G. J. Baker, Eds., Food Industries Manual, Chapman \& Hall, London, 1995, p. 151.

[8] A. P. Bartolomé, P. Rupérez and C. Fúster, "Pineapple Fruit: Morphological Characteristics, Chemical Composition and Sensory Analysis of Red Spanish and Smooth Cayenne Cultivars,” Food Chemistry, Vol. 53, No. 1, 1995, pp. 75-79. doi:10.1016/0308-8146(95)95790-D

[9] J. A. Duke, “Handbook of Energy Crops,” Unpublished, 1983.

[10] J. A. Samson, “Tropical Fruits,” 2nd Edition, Longman Inc., New York, 1986.

[11] S. K. Adhikari, W. P. Harkare, K. P. Govindan, K. C. 
Chikkappaji, S. Saroja and A. M. Nanjundaswamy, "Deacidification of Fruit Juices by Electrodialysis. Part II,” Indian Journal of Technology, Vol. 25, 1987, p. 24.

[12] P. Biginelli, "Derivati Aldeiduredici Degli Eteri Acetile Dossal-Acetico," Gazzetta Chimica Italiana, Vol. 23, 1893, pp. 360-416.

[13] G. C. Rovnyak, S. D. Kimall, B. Beyer, G. Cucinotta, J. D. DiMarco, J. Gougoutas, A. Hedberg, M. Malley and J. P. McCarthy, "Calcium Entry Blockers and Activators: Conformational and Structural Determinants of Dihydropyrimidine Calcium Channel Modulators,” Journal of Medicinal Chemistry, Vol. 38. No. 1, 1995, pp. 119-129. doi:10.1021/jm00001a017

[14] K. S. Atwal, G. C. Rovnyak, J. Schwartz, S. Moreland, A. Hedberg, J. Z. Gougoutas, M. F. Malley and D. M. Floyd, "Dihydropyrimidine Calcium Channel Blockers: 2-Heterosubstituted 4-Aryl-1,4-dihydro-6-methyl-5-pyrimidinecarboxylic Acid Esters as Potent Mimics of Dihydropyridines,” Journal of Medicinal Chemistry, Vol. 33, No. 5, 1990, pp. 1510-1515. doi:10.1021/jm00167a035

[15] K. S. Atwal, G. C. Rovnyak, S. D. Kimball, D. M. Floyed, B. N. Moreland, S. Swanson, J. Z. Gougoutas, J. Schwartz, K. M. Smillie and M. F. Malley, "Dihydropyrimidine Calcium Channel Blockers. II. 3-Substituted4-aryl-1,4-dihydro-6-methyl-5-pyrimidinecarboxylic Acid Esters as Potent Mimics of Dihydropyridines," Journal of Medicinal Chemistry, Vol. 33, No. 9, 1990, pp. 2629-2635. doi:10.1021/jm00171a044

[16] J. J. Baldwin, D. A. Claremon and D. E. McClure, "5Acetyl-3,4,5,6-Tetrahydro-4-Oxo-2,6-Methano-2H-1,3,5Benzothiazocine(benzodiazocine)-11-Carboxylates Useful as Calcium Channel Blockers,” US Patent No. 4609494, 1986.

[17] J. J. Baldwin, S. M. Ptizenberger and D. E. McClure, "Substituted Pyrimidines Useful as Calcium Channel Blockers,” US Patent No. 4675321, 1987.

[18] K. S. Atwal, “1,2,3,4-Tetrahydro-6-Substituted-4-Aryl3-(Substitutedsfonyl)-2-thioxo(oroxo)-5-pyrimidinecarBoxylic Acids and Esters and Method of Using Them to Lower Blood Pressure,” US Patent No. 4684656, 1987.

[19] H. Cho, M. Ueda, K. Shima, A. Mizuno, M. Hayashimatsu, Y. Ohnaka, Y. Takeuchi, M. Hamaguchi, K. Aisaka, T. Hidaka, M. Kawai, M. Takeda, T. Ishihara, K. Funahashi, F. Satoh, M. Morita and T. Noguchi, "Dihydropyrimidines: Novel Calcium Antagonists with Potent and Long-Lasting Vasodilative and Anti-Hypertensive Activity," Journal of Medicinal Chemistry, Vol. 32, No. 10, 1989, pp. 2399-2406. doi:10.1021/jm00130a029

[20] T. Boumoud, B. Boumoud, S. Rhouati, A. Belfaitah, A. Deache and P. Mosset, "A Novel Catalyst for One-Pot Synthesis of Substituted 3,4-Dihydropyrimidin-2-(1H)ones via Biginelli Reaction Under Solvent-Free Conditions," Acta Chimica Slovenica, Vol. 55, 2008, pp. 617622.

[21] T. Boumoud, B. Boumoud, S. Rhouati, A. Belfaitah, A. Deache and P. Mosset, "An Efficient and Recycling Catalyst for the One-Pot Three-Component Synthesis of Substituted 3,4-Dihydropyrimidin-2(1H)-ones,” E-Jour- nal of Chemistry, Vol. 5, No. 4, 2008, pp. 688-695.

[22] J. Lu, Y. Bai, Z. Wang, B. Yang and H. Ma, “One-Pot Synthesis of 3,4-Dihydropyrimidin-2(1H)-ones Using Lanthanum Chloride as a Catalyst," Tetrahedron Letters, Vol. 41, No. 47, 2000, pp. 9075-9078. 7doi:10.1016/S0040-4039(00)01645-2

[23] M. B. Deshmukh, P. V. Anbhule, S. D. Jadhav, A. R. Mali, S. S. Jagtap and S. A. Deshmukh, "An Efficient, Simple, One Pot Synthesis of Dihydropyrimidine-2(1H)ones Using Phosphorus Pentoxide," Indian Journal of Chemistry, Vol. 46B, No. 9, 2007, pp. 1545-1548.

[24] D. Shobha, M. A. Chari, P. Sadanandam and K. Mukkanti, "Dichloro Dicyano Quinone (DDQ) as Coupling Reagent for High Yield Synthesis of 3,4-Dihydropyrimidin-2-(1H)-ones," Journal of Heterocyclic Chemistry, Vol. 45, 2008, pp. 1225-1227.

[25] N. Y. Fu, M. L. Pang, Y. F. Yuan and J. T. Wang, "Indium(III)tribromide: An Excellent Catalyst for Biginelli Reaction," Chinese Chemical Letters, Vol. 10, 2002, pp. 921-922.

[26] B. Gangadasu, P. Narender, B. C. Raju and V. J. Rao, "Calcium Chloride Catalyzed Three Component, One-Pot Condensation Reaction: An Efficient Synthesis of 3,4Dihy-dropyrimidin-2(1h)-ones," Indian Journal of Chemistry, Vol. 45B, No. 6, 2006, pp. 1259-1263.

[27] G. Aridoss and Y. T. Jeong, “A Convenient One-Pot Biginelli Reaction Catalyzed by $\mathrm{Y}(\mathrm{OAc})_{3}$ : An Improved Protocol for the Synthesis of 3,4-Dihydropyrimidin2(1H)-ones and Their Sulfur Analogues,” Bulletin of the Korean Chemical Society, Vol. 31, No. 4, 2010, pp. 863868. doi:10.5012/bkcs.2010.31.04.863

[28] M. A. Pasha, N. R. Swamy and V. P. Jayshankara, "One Pot Synthesis of 3,4-Dihydropyrimidin-2(1H)-Ones/-ThiOnes Catalysed by Zinc Chloride: An Improved Procedure for the Biginelli Reaction Using Microwaves under Solvent Free Condition," Indian Journal of Chemistry, Vol. 44B, No. 3, 2005, pp. 823-826.

[29] S. L. Jain, V. B. Sharma and B. Sain, "Ruthenium-Catalyzed Biginelli Condensation: A Simple and Efficient One-Pot Synthesis of 3,4-Dihydropyrimidin-2(1H)-ones under Mild Reaction Conditions,” Journal of Heterocyclic Chemistry, Vol. 43, No. 3, 2006, pp. 777-779. doi:10.1002/ihet.5570430339

[30] I. Suzuki, Y. Suzumura and K. Takeda, "Metal Triflimide as a Lewis Acid Catalyst for Biginelli Reactions in Water,” Tetrahedron Letters, Vol. 47, 2006, pp. 7861-7864. doi:10.1016/j.tetlet.2006.09.019

[31] T. Jin, S. Zhang, T. Li, " $p$-Toluenesulfonic Acid-Catalyzed Efficient Synthesis of Dihydropyrimidines: Improved High Yielding Protocol for the Biginelli Reaction," Synthetic Communications, Vol. 32, 2002, pp. 1847-1851.

[32] S. K. Kundu, A. Majee and A. Hajra, "Environmentally Benign Aqueous Zinc Tetrafluoroborate-Catalyzed OnePot Biginelli Condensation at Room Temperature,” Indian Journal of Chemistry, Vol. 48B, No. 3, 2009, pp. 408-412. 
[33] H. Adrienn, H. Zolta'n and V. Ilona, “Convenient OnePot Heterogeneous Catalytic Method for the Preparation of 3,4-Dihydropyrimidin-2(1H)-ones," Synthetic Communications, Vol. 36, 2006, pp. 129-136.

[34] H. N. Karade, M. Sathe and M. P. Kaushik, "Synthesis of 4-Aryl Substituted 3,4-Dihydropyrimidinones Using Silica-Chloride under Solvent Free Conditions,” Molecules, Vol. 12, 2007, pp. 1341-1351.

[35] S. Hashem and J. Mahboubeh, “ $\mathrm{Al}_{2} \mathrm{O}_{3} / \mathrm{MeSO}_{3} \mathrm{H}$ : A Novel and Recyclable Catalyst for One-Pot Synthesis of 3,4Dihydropyrimidinones or Their Sulfur Derivatives in Biginelli Condensation,” Synthetic Communications, Vol. 39, 2009, pp. 958-979.

[36] F. Bigi, S. Carloni, B. Fraullanti, R. Maggi and G. Sartori, "A Revision of the Biginelli Reaction under Solid Acid Catalysis. Solvent-Free Synthesis of Dihydropyrimidines over Montmorillonite KSF,” Tetrahedron Letters, Vol. 40, No. 17, 1999, pp. 3465-3468. doi:10.1016/S0040-4039(99)00424-4

[37] V. R. Rani, N. Srinivas, M. R. Kishan, S. J. Kulkarni and K. V. Raghavan, "Zeolite-Catalyzed Cyclocondensation
Reaction for the Selective Synthesis of 3,4-Dihydropyrimidin-2(1H)-ones," Green Chemistry, Vol. 3, No. 6, 2001, pp. 305-306. doi:10.1039/b107612b

[38] V. Singh, S. Kaur, R. Ratti, G. L. Kad and J. Singh, "Acidic Task Specific Ionic Liquid Catalyzed Synthesis of Dipyrimidinones," Indian Journal of Chemistry, Vol. 49B, No. 5, 2010, pp. 611-616.

[39] W. Y. Chen, S. D. Qin and J. R. Jin, "Efficient Biginelli Reaction Catalyzed by Sulfamic Acid or Silica Sulfuric Acid under Solvent-Free Conditions," Synthetic Communications, Vol. 37, 2007, pp. 47-52.

[40] S. Ramalingam and P. Kumar, "Yttria-Zirconia-Based Lewis Acid Catalysis of the Biginelli Reaction: An Efficient One-Pot Synthesis of 3,4-Dihydropyrimidin-2-(1H)ones," Synthetic Communications, Vol. 39, 2009, pp. 1299-1309.

[41] T. B. Shah, A. Gupte, M. R. Patel, V. S. Chaudhari, H. Patel and V. C. Patel, "Synthesis and in Vitro Study of Biological Activity of Heterocyclic N-Mannich Bases," Indian Journal of Chemistry, Vol. 48B, No. 1, 2009, pp. 88-96. 